Provided for non-commercial research and education use. Not for reproduction, distribution or commercial use.

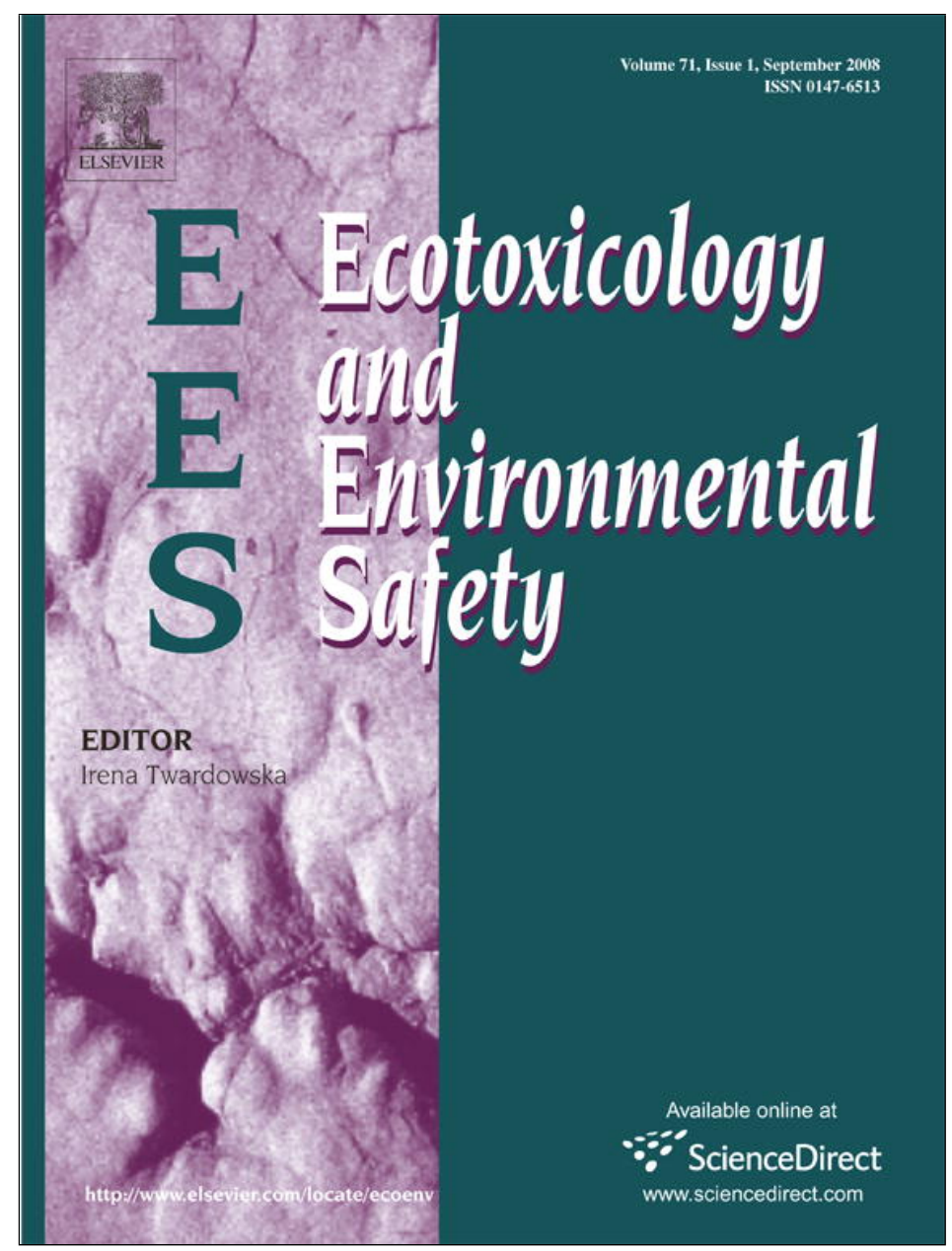

This article appeared in a journal published by Elsevier. The attached copy is furnished to the author for internal non-commercial research and education use, including for instruction at the authors institution and sharing with colleagues.

Other uses, including reproduction and distribution, or selling or licensing copies, or posting to personal, institutional or third party websites are prohibited.

In most cases authors are permitted to post their version of the article (e.g. in Word or Tex form) to their personal website or institutional repository. Authors requiring further information regarding Elsevier's archiving and manuscript policies are encouraged to visit:

http://www.elsevier.com/copyright 


\title{
Modelling metallothionein induction in the liver of Sparus aurata exposed to metal-contaminated sediments
}

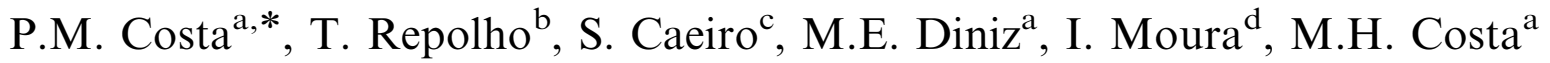 \\ ${ }^{a}$ IMAR-Instituto do Mar, DCEA, Faculdade de Ciências e Tecnologia da Universidade Nova de Lisboa, 2829-516 Monte de Caparica, Portugal \\ ${ }^{\mathrm{b}}$ Departamento de Biologia-Universidade de Aveiro, Campus Universitário de Santiago, 3810-193 Aveiro, Portugal \\ 'IMAR-Instituto do Mar, Departamento de Ciencias Exactas e Tecnológicas-Universidade Aberta, rua da Escola Politécnica, 141, 1269-001 Lisboa, Portugal \\ ${ }^{\mathrm{d}}$ REQUIMTE-Rede de Química Tecnológica, Departamento de Química-Faculdade de Ciências e Tecnologia da Universidade Nova de Lisboa, \\ 2829-516 Monte de Caparica, Portugal
}

Received 30 January 2007; received in revised form 12 April 2007; accepted 3 May 2007

Available online 6 July 2007

\begin{abstract}
Metallothionein (MT) in the liver of gilthead seabreams (Sparus aurata L., 1758) exposed to Sado estuary (Portugal) sediments was quantified to assess the MT induction potential as a biomarker of sediment-based contamination by copper $(\mathrm{Cu})$, cadmium $(\mathrm{Cd})$, lead $(\mathrm{Pb})$ and arsenic (As). Sediments were collected from two control sites and four sites with different levels of contamination. Sediment $\mathrm{Cu}$, $\mathrm{Cd}, \mathrm{Pb}, \mathrm{As}$, total organic matter (TOM) and fine fraction (FF) levels were determined. Generalized linear models (GLM) allowed integration of sediment parameters with liver $\mathrm{Cu}, \mathrm{Cd}, \mathrm{Pb}, \mathrm{As}$ and $\mathrm{MT}$ concentrations. Although sediment metal levels were lower than expected, we relate MT with liver $\mathrm{Cd}$ and also with interactions between liver and sediment $\mathrm{Cu}$ and between liver $\mathrm{Cu}$ and TOM. We suggest integrating biomarkers and environmental parameters using statistical models such as GLM as a more sensitive and reliable technique for sediment risk assessment than traditional isolated biomarker approaches.
\end{abstract}

(C) 2007 Elsevier Inc. All rights reserved.

Keywords: Sparus aurata; Metallothionein; Biomarker; Heavy metals; Sado estuary; Generalized linear models; Sediment risk assessment

\section{Introduction}

Metallothioneins (MTs), first described by Margoshes and Vallee (1957), are small (6-7 kDa) cytosolic proteins involved in metal homeostasis and detoxification processes that contain about 60 amino acids (none of which aromatic) and a high content of cysteine residues. MTs have two globular subunits, each comprising about 10 cysteine residues that do not form disulfide bonds and are responsible for sequestering metals with their sulphydryl (thiolic) groups. These proteins are very conservative even between distinct animal groups and have been widely used as biomarkers of metal exposure in aquatic organisms since

\footnotetext{
The animals used in the present work were handled according to the guidelines for the welfare of laboratory animals, regarding rearing, testing and analysis procedures.

*Corresponding author. Fax: + 351212948554

E-mail address: pmcosta@fct.unl.pt (P.M. Costa).
}

there is induction of MT synthesis resulting from exposure to metallic pollutants (Romero-Isart and Vašák, 2002).

MT induction is variable within metals. Cadmium, for instance, is one of the strongest known MT inducers (e.g. Olsson and Haux, 1986; Wan et al., 1993). MTs are present in all tissues but gills and liver are the most usually surveyed organs for MT induction in fish, due to their role in metal uptake and bioaccumulation/detoxification, respectively (Hamza-Chaffai et al., 1995). Fish blood has also been analyzed for MT induction as a result of heavy-metal exposure, but without evident overexpression (Fulladosa et al., 2006).

Sparus aurata is a cosmopolitan coastal demersal species of the NE Atlantic and Mediterranean that often inhabits estuarine areas, at least during early life stages. This species has a high economical value and is one of the most important closed-cycle mariculture productions in southern Europe, especially in Portugal. These characteristics provide the gilthead seabream with particular interest as 
a potential indicator species. $S$. aurata MT has a molecular weight of $5.966 \mathrm{kDa}$ and contains 20 metal-binding cysteine residues (Tom et al., 1998) and has already been proposed as a biomarker of heavy-metal exposure (Tom et al., 1998, 2004; Cousinou et al., 1999).

The Sado estuary is an area very susceptible to metal contamination, since it receives urban discharges from the city of Setúbal, industrial wastewaters from the city's extensive industrial belt (one of Portugal's highest concentration of heavy industries, including shipyards, paper mills and mineral ore treatment and deployment facilities) and runoffs from agricultural grounds located upstream. The estuary is also a very important leisure, fishing and aquaculture area. Part of the estuary is classified as a natural reserve, which contributes for the conflict between natural environment preservation and anthropogenic usage and alterations. For these reasons, this estuary is subjected to an increasing interest on environmental risk monitoring and ecotoxicology, particularly regarding sediment risk assessment. However, sediment risk analysis has many constraints since there are several parameters that influence sediment contaminants' bioavailability and also because estuaries are labile environments, subjected to changes caused by natural environmental factors and anthropogenic alterations such as dredgings and point pollutant discharges. Therefore, further research is now following multivariate approaches regarding sediment risk assessment in confined coastal areas (DelValls et al., 2002; Caeiro et al., 2005; Neuparth et al., 2005), including sediment toxicity analysis using $S$. aurata as test organism (DelValls et al., 1998).

This work aims to assess the value of MT induction as a biomarker of exposure to sediment-based metallic contamination, namely an essential metal, copper $(\mathrm{Cu})$, two non-essential metals, cadmium $(\mathrm{Cd})$ and lead $(\mathrm{Pb})$, and a metalloid (As). For this purpose, MT induction is integrated with sediment parameters: $\mathrm{Cu}, \mathrm{As}, \mathrm{Cd}$ and $\mathrm{Pb}$ levels, fine fraction (FF) and total organic matter (TOM) in order to contribute to sediment risk assessment in the practical context of the Sado estuary.

\section{Materials and methods}

\subsection{Experimental assay}

Sediments were collected from six stations in the Sado estuary (Fig. 1), chosen according to their different metallic concentrations determined in previous surveys (Caeiro et al., 2005). Stations C1 and C2 (Tróia peninsula) were considered control (pristine) sites according to available data.

Juvenile $S$. aurata $(3.95 \pm 0.83 \mathrm{~g}$ total wet weight) obtained from a mariculture facility (TIMAR/Ria-Mãe, Setúbal, Portugal) were subjected to dynamic 10-day assays in $12 \mathrm{~L}$ aerated tanks $\left(\mathrm{DO}_{2}>5 \mathrm{ppm}\right)$, each containing $2 \mathrm{~L}$ of collected sediments, with a $12 \mathrm{~h}$ light/dark photoperiod. Animals were acclimated to laboratory environment for 15 days. Sediments were sieved through a $5-\mathrm{mm}$ mesh upon collection and stored in the dark at $4{ }^{\circ} \mathrm{C}$ for $48 \mathrm{~h}$ prior to assay assembly. Assays were performed in triplicate and each tank held eight randomly selected individuals. Temperature was maintained constant at $18^{\circ} \mathrm{C}$ and salinity was 35 . Fish

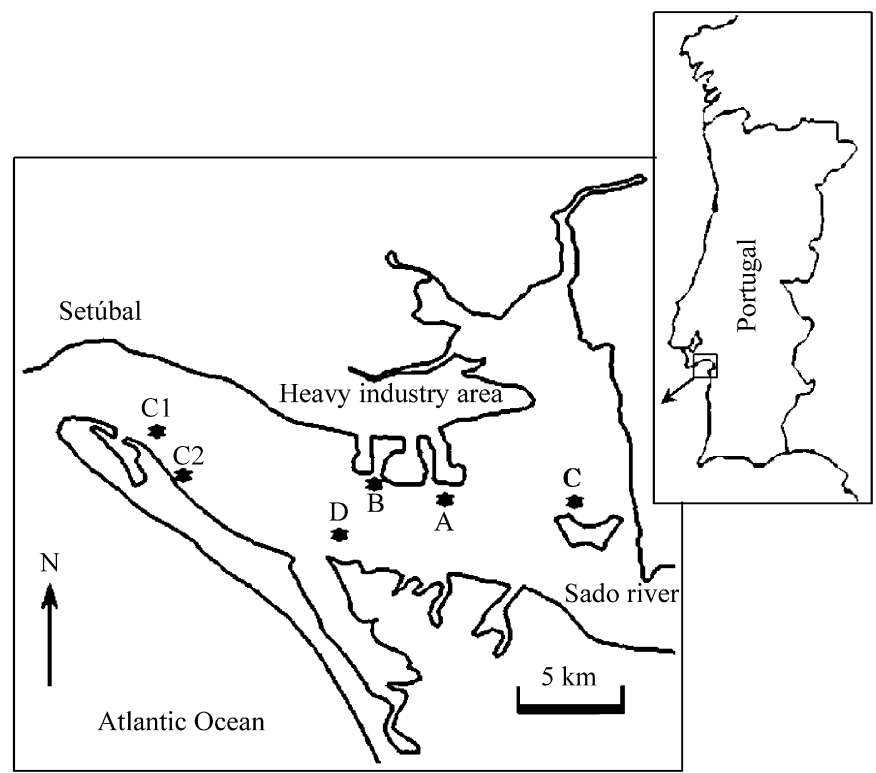

Fig. 1. Map of the study area (Sado estuary) showing sediment sampling sites $(*)$.

were fed on a daily basis with commercial pellets (Dibaq, Spain) and onethird of the total water volume was changed each day. At the end of the assays, fish were sacrificed and the liver was excised, sub-divided for several biochemical analyses and stored at $-80^{\circ} \mathrm{C}$. Liver portions from 12 individuals per test (four per replicate) were analyzed for MT induction and metal concentration.

\subsection{Quantification of liver $M T$}

Liver samples (16.30-187.40 mg wet weight) were homogenized on ice in TRIS- $\mathrm{HCl} 0.02 \mathrm{M}$ buffer ( $\mathrm{pH} 8.6$ ) and centrifuged for $1 \mathrm{~h}$ at $30,000 \mathrm{~g}$ $\left(\right.$ at $4{ }^{\circ} \mathrm{C}$ ). The supernatant was then heated at $\approx 80^{\circ} \mathrm{C}$ for $10 \mathrm{~min}$ to denaturate non-heat resistant proteins and centrifuged $(1 \mathrm{~h}, 30,000 \mathrm{~g}$ at $4{ }^{\circ} \mathrm{C}$ ) to precipitate the majority of non-heat resistant and high molecular weight (HMW) proteins. MT quantification was performed by differential pulse polarography (DPP) with a static mercury drop electrode (SMDE) using a Metrohm 694 stand and a 693 processor. The electrode system consisted of a mercury capillary working electrode, an $\mathrm{Ag} / \mathrm{AgCl}$ reference electrode and a platinum auxiliary electrode.

Laboratory reared, unexposed, animals were used to establish MT extraction and quantification techniques, which revealed the most favorable loading volumes for the polarographic cell in order to obtain a good signal and a minimal standard error: $20 \mathrm{~mL}$ of the Brdička supporting electrolyte, $250 \mu \mathrm{L}$ of Triton-X $100(0.025 \% \mathrm{v} / \mathrm{v})$ and $250 \mu \mathrm{L}$ of sample. The supporting electrolyte $\left(1 \mathrm{M} \mathrm{NH}_{4} \mathrm{Cl}, 1 \mathrm{M} \mathrm{NH} \mathrm{NH}_{4} \mathrm{OH}\right.$ and $2 \mathrm{mM}$ $\left[\mathrm{Co}\left(\mathrm{NH}_{3}\right)_{6}\right] \mathrm{Cl}_{3}$ ) was prepared weekly and stored at $4{ }^{\circ} \mathrm{C}$ (Palecek and Pechan, 1971). Standard-addition was the method employed to quantify MT, through two $250 \mu \mathrm{L}$ additions of $10 \mathrm{mg} \mathrm{L}^{-1}$ rabbit MT forms I and II standard (Sigma), in the absence of a purified $S$. aurata MT. Results are expressed as rabbit-MT equivalents $\mathrm{mgg}^{-1}$ dry weight (dw) of liver homogenate. MT extraction and quantification procedures by DPPSMDE using rabbit MT as standard were adapted for $S$. aurata MT from Bebianno and Langston (1989).

\subsection{MT purification and electrophoretic analysis}

Composite samples of heat-treated homogenates were centrifuged at $12,000 \mathrm{~g}$ for $15 \mathrm{~min}$ at $4{ }^{\circ} \mathrm{C}$ to precipitate remaining $\mathrm{HMW}$ protein and concentrated with a $5 \mathrm{kDa}$ membrane pore Amicon ultrafiltration cell before protein fractioning by chromatography. The concentrated heattreated homogenates were fractioned by high performance liquid 
chromatography (HPLC) with a $26 \times 700 \mathrm{~mm}$ Sephadex G-75 gel filtration column (Amersham) in $50 \mathrm{mM}$ Tris- $\mathrm{HCl}$ buffer (pH 7.6) with $150 \mathrm{mM}$ $\mathrm{NaCl}$. Monitoring was performed using a Jasco PU-980 pump and a Jasco 975 UV detector and chromatography curves were recorded using an LKB 2210 apparatus. Protein fractions and rabbit MT standard were afterwards concentrated using $3 \mathrm{kDa}$ membrane pore Centricon ultrafiltration cells and the presence of $S$. aurata MT was determined by comparison with rabbit MT standard in gels. MT was visualized in sodium dodecyl sulfate polyacrylamide gel electrophoresis (SDS-PAGE), with a $15 \%$ acrylamide in $0.25 \mathrm{M}$ Tris- $\mathrm{HCl}$ buffer $(\mathrm{pH} 8.8)$ resolving gel and a $5 \%$ acrylamide in $0.125 \mathrm{M}$ Tris- $\mathrm{HCl}$ buffer (pH 6.8) stacking gel. Gel thickness was $0.75 \mathrm{~mm}$. Prior to electrophoresis samples were heated at $100^{\circ} \mathrm{C}$ for $2 \mathrm{~min}$ in SDS sample buffer containing $\beta$-mercaptoethanol. Gels were stained with Coomassie Brilliant Blue. Protein standards (Bio-Rad) were used as molecular weight standards for electrophoresis: aprotinin $(7.50 \mathrm{kDa})$, lysozyme $(20.60 \mathrm{kDa})$, soybean trypsin inhibitor $(28.90 \mathrm{kDa})$, carbonic anhydrase $(34.80 \mathrm{kDa})$, ovalbumin $(49.10 \mathrm{kDa})$, bovine serum albumin $(80.00 \mathrm{kDa}), \quad \beta$-galactosidase $(124.00 \mathrm{kDa})$ and myosin $(209.00 \mathrm{kDa})$. MT molecular weight was determined by comparison of band migration distances with molecular weight standards using the software Quantity One 4.2.2 (Bio-Rad).

\subsection{Quantification of liver $\mathrm{Cu}, \mathrm{As}, \mathrm{Cd}$ and $\mathrm{Pb}$}

Liver $\mathrm{Cu}, \mathrm{As}, \mathrm{Cd}$ and $\mathrm{Pb}$ concentrations were determined by inductively coupled plasma atomic emission spectrometry (ICP-EAS) using a Thermo Unicam $\mathrm{X}$ Series apparatus, after digestion of liver homogenate aliquots with $\mathrm{HNO}_{3}$ and $\mathrm{H}_{2} \mathrm{O}_{2}$ (Clescer et al., 1999). Dogfish liver reference material (DOLT-3, NRC-CNRC, Canada) was analyzed through the same procedure to validate the protocol and the measured values were found within the certified range. Results are expressed in metal $\mathrm{mg} \mathrm{kg}^{-1} \mathrm{dw}$ of liver homogenate.

\subsection{Sediment analysis}

Sediment FF (particle size $<63 \mu \mathrm{m}$ ) was obtained by removal of organic matter with $\mathrm{H}_{2} \mathrm{O}_{2}$, followed by disaggregation in pyrophosphate, washing and hydraulic sieving. Results are expressed in dw percentage of $\mathrm{FF}$ in relation to sediment total $\mathrm{dw}$. Sediment TOM was quantified from subsamples by total ignition at $500 \pm 25^{\circ} \mathrm{C}$ for $4 \mathrm{~h}$. Results are expressed in weight percentage of organic matter relatively to sediment dw. Regarding $\mathrm{Cu}, \mathrm{As}, \mathrm{Cd}$ and $\mathrm{Pb}$ quantification, subsamples of tested sediments were analyzed by ICP-EAS (Horiba-Jobin Yvon, model Ultima) after digestion according to USEPA (1996) methods. Sediment reference materials (LKSD-1, NRC, Canada and SRM-2782, NIST, USA) were analysed to validate the procedure and measured values were found within the certified range. Metal contents are expressed in $\mathrm{m} \mathrm{kg}^{-1}$ sediment $\mathrm{dw}$.

\subsection{Statistical analysis}

Data were analyzed using generalized linear models, GLM (Nelder and Wedderburn, 1972), through a Gamma distribution regression (for continuous and positive data) with an inverse link function. The goal was to assess the effect of the linear predictors (independent variables), isolated or interacting, upon liver MT (dependent variable). Linear predictors consisted of the concentration of each metal in liver and sediments, TOM and FF. Model validation was obtained according to normality and dispersion of Pearson residuals. Analysis follows essentially McCullagh and Nelder (1989).

Relative importance of each model component was obtained through analysis of variance (ANOVA) based on the comparison of deviance reduction imposed by each added model component. Significance of each component was obtained by $F$-tests $(\alpha=0.05)$. Inference on coefficients was obtained through $t$-tests $(\alpha=0.05)$ in order to assess the significance of positive or negative influences of linear predictors upon liver MT concentration. GLM analysis was performed using R software package version 2.3.1 (Ihaka and Gentleman, 1996) and basic statistics and graphics were computed with Statsoft Statistica 6.0.

\section{Results}

\subsection{MT purification and electrophoretic analysis}

Heat-treated homogenates were successfully fractioned by HPLC and the MT fraction was visualized in SDSPAGE gels and compared with MT standard (Figs. 2 and 3). Extraction by HPLC revealed that homogenates still had a considerable portion of HMW proteins after heat treatment. The relatively small MT peak reveals that MT is present in lesser concentrations than other cytosolic proteins not removed by heat-treatment. Gels showed that S. aurata MT and rabbit MT standard have a similar pattern. Molecular weight determined by migration distance was approximately: 91 and $80 \mathrm{kDa}$ for $S$. aurata MT forms I and II, respectively, and 95 and $81 \mathrm{kDa}$ for rabbit MT forms I and II, respectively. Some difficulties were found when concentrating the purified protein, most likely due to its small size: $5 \mathrm{kDa}$ pore membranes were proven less effective than $3 \mathrm{kDa}$ regarding the procedure to concentrate the purified protein.

\subsection{Quantification of $\mathrm{Cu}, \mathrm{As}, \mathrm{Cd}, \mathrm{Pb}$ and $\mathrm{Mt}$ in the liver}

In Table 1 are presented the measured liver $\mathrm{Cu}, \mathrm{As}, \mathrm{Cd}$, $\mathrm{Pb}$ and MT levels. Polarographic curves of $S$. aurata and standard (rabbit) MTs were found similar, which demarked electrochemical compatibility for DPP-SMDE.

Quantification of liver MT exhibited great variability within sites (Fig. 4). No statistically significant differences were detected between sites (Kruskall-Wallis ANOVA by ranks, $H=8.72, p>0.05)$. Regarding liver metal concentrations, differences were only observed between sites regarding $\mathrm{Cu}$ (Kruskall-Wallis ANOVA by ranks, $H=36.17, p \approx 0.00$ ) and $\mathrm{Pb}$ (Kruskall-Wallis ANOVA by ranks, $H=15.18, p<0.01)$. The failure of classical ANOVA to detect differences between control and test

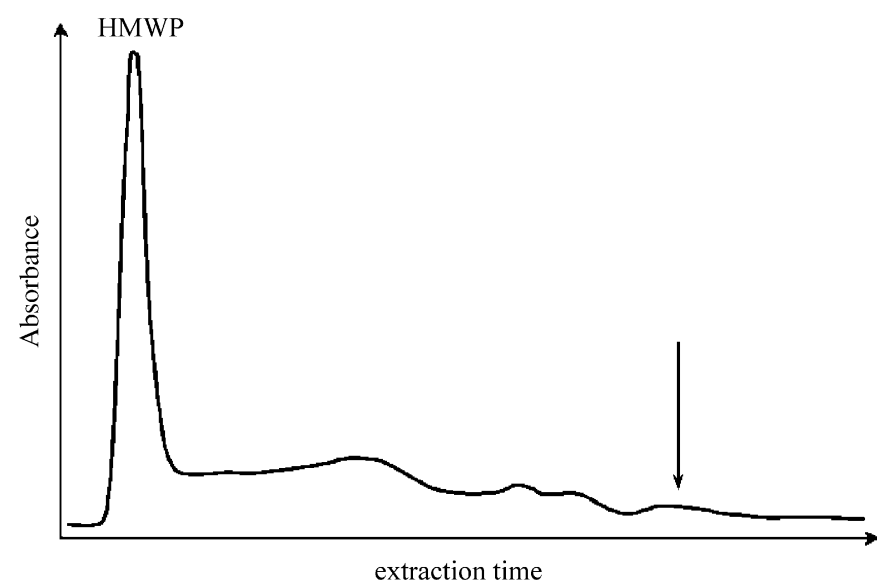

Fig. 2. Chromatography curve of $S$. aurata liver homogenate showing MT fraction (arrow). HMWP indicates HMW protein peak. 


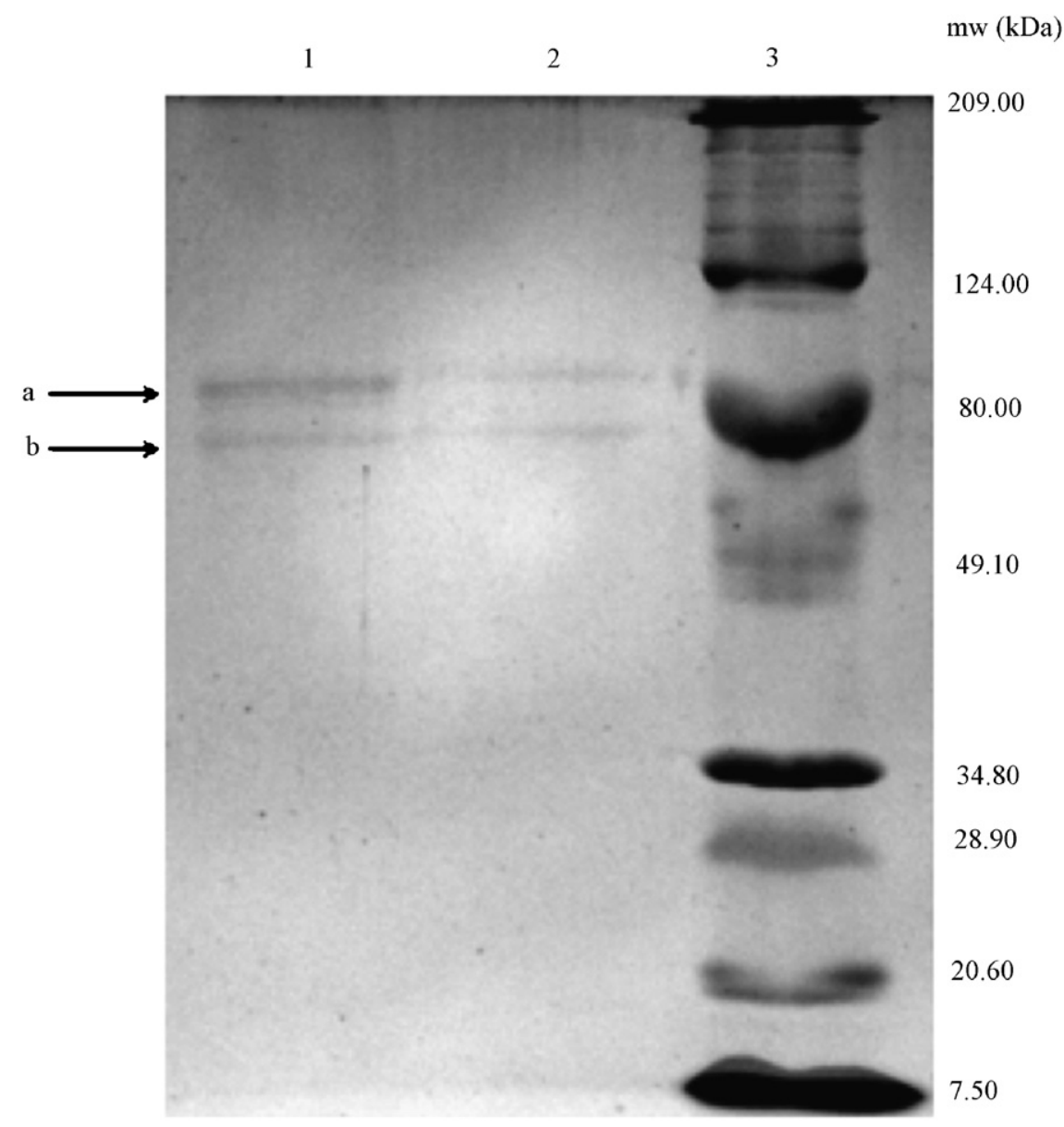

Fig. 3. SDS-PAGE electrophoresis of S. aurata MT (1), rabbit MT (2) and molecular weight (mw) standards (3). Arrows: (a) polymerized MT-form I and (b) polymerized MT-form II.

Table 1

Quantification averages and average standard errors of metal (in $\mathrm{mg} \mathrm{kg}^{-1} \mathrm{dw}$ ) and MT (in $\mathrm{mg} \mathrm{g}^{-1} \mathrm{dw}$ ) in the liver of exposed S. aurata

\begin{tabular}{lcrrrl}
\hline Site & $\mathrm{Cu}$ & \multicolumn{1}{l}{$\mathrm{As}$} & $\mathrm{Cd}$ & $\mathrm{Pb}$ & $\mathrm{MT}$ \\
\hline $\mathrm{C} 1$ & $454.89 \pm 45.61$ & $4.65 \pm 0.85$ & $31.59 \pm 2.37$ & $299.54 \pm 23.43$ & $2.48 \pm 0.04$ \\
$\mathrm{C} 2$ & $94.27 \pm 13.31$ & $3.34 \pm 0.70$ & $3.66 \pm 1.92$ & $153.99 \pm 23.77$ & $2.41 \pm 0.05$ \\
$\mathrm{~A}$ & $354.85 \pm 37.60$ & $4.89 \pm 0.66$ & $25.68 \pm 2.22$ & $269.11 \pm 27.32$ & $1.39 \pm 0.02$ \\
$\mathrm{~B}$ & $331.18 \pm 42.28$ & $7.92 \pm 1.07$ & $12.69 \pm 1.94$ & $163.02 \pm 21.88$ & $1.56 \pm 0.03$ \\
$\mathrm{C}$ & $126.43 \pm 12.49$ & $10.41 \pm 1.09$ & $3.51 \pm 0.34$ & $36.89 \pm 3.64$ & $2.47 \pm 0.05$ \\
$\mathrm{D}$ & $23.50 \pm 3.32$ & $2.57 \pm 0.51$ & $0.60 \pm 0.32$ & $19.37 \pm 2.73$ & $2.04 \pm 0.08$
\end{tabular}

sites confirmed the need for a statistical model that could explain the variability of MT levels between all six sites.

\subsection{Sediment analysis}

Table 2 summarizes the data collected from the sediments. Sediment metal content differs from what was previously detected in the same sampling areas by Caeiro et al. (2005): $\mathrm{Cd}$ and As presented lower levels than expected whereas $\mathrm{Cu}$ and $\mathrm{Pb}$ presented higher ones. This may be caused by factors affecting estuarine sediments, such as dredgings, which are performed often in the Sado

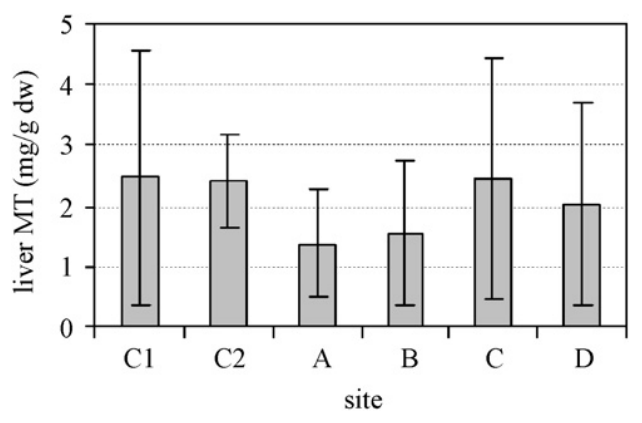

Fig. 4. Liver MT averages and respective standard deviations.

estuary due to its importance for maritime transport. A minor role could be played by the natural heterogeneity of surface estuarine sediments. As expected, FF and TOM depicted a linear relationship (Fig. 5).

\subsection{GLM analysis}

Three models were formulated to explain the variables' influence upon MT levels: the main effects model, to assess the relative importance of each linear predictor, and two interaction models to assess the relevance of the interactions: liver metal concentration*sediment metal 
Table 2

Sediment parameters

\begin{tabular}{lrrllrr}
\hline Site & \multicolumn{1}{l}{$\mathrm{Cu}$} & \multicolumn{1}{l}{ As } & $\mathrm{Cd}$ & $\mathrm{Pb}$ & \multicolumn{1}{l}{$\mathrm{FF}$} & \multicolumn{1}{l}{$\mathrm{TOM}$} \\
\hline $\mathrm{C} 1$ & $1.75 \pm 0.02$ & $3.34 \pm 0.15$ & $0.08 \pm 0.17$ & $2.25 \pm 0.23$ & $0.64 \%$ & $0.38 \%$ \\
$\mathrm{C} 2$ & $1.97 \pm 0.01$ & $2.39 \pm 0.09$ & $0.08 \pm 0.17$ & $2.47 \pm 0.26$ & $0.35 \%$ & $0.46 \%$ \\
$\mathrm{~A}$ & $72.04 \pm 0.36$ & $10.94 \pm 0.82$ & $0.09 \pm 0.00$ & $32.19 \pm 0.39$ & $9.21 \%$ & $1.44 \%$ \\
$\mathrm{~B}$ & $120.69 \pm 2.41$ & $27.44 \pm 0.69$ & $0.08 \pm 0.00$ & $57.86 \pm 1.04$ & $58.79 \%$ & $10.38 \%$ \\
$\mathrm{C}$ & $56.05 \pm 0.39$ & $19.37 \pm 1.67$ & $0.08 \pm 0.01$ & $41.71 \pm 0.83$ & $60.30 \%$ & $8.63 \%$ \\
$\mathrm{D}$ & $27.50 \pm 0.44$ & $14.70 \pm 3.53$ & $0.08 \pm 0.00$ & $22.41 \pm 0.61$ & $28.83 \%$ & $6.07 \%$
\end{tabular}

Metal concentration is given in $\mathrm{mg} \mathrm{kg}^{-1} \mathrm{dw}$ and $\mathrm{FF}$ and TOM in $\% \mathrm{dw}$.

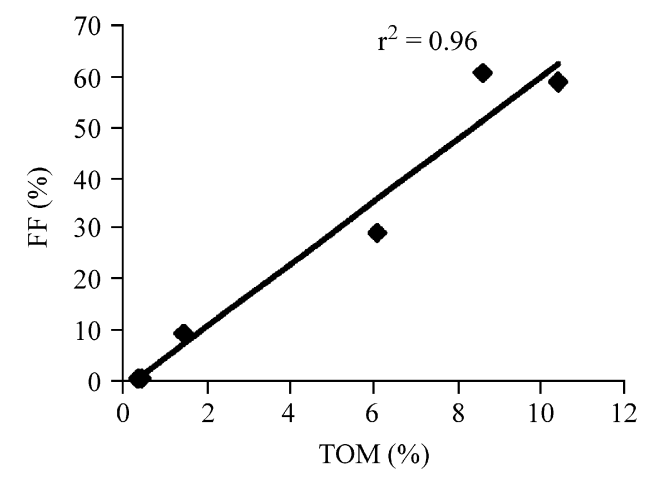

Fig. 5. Relationship between TOM and FF of tested sediments. concentration and liver and sediment metal concentration*TOM. Due to the relationship between TOM and $\mathrm{FF}$, the interaction $\mathrm{TOM} * \mathrm{FF}$ was included in the interaction models as contrast. Outliers were removed before GLM analysis. Higher order interaction models (such as interaction between metals) were not computable due to the high number of model parameters to be estimated in relation to the number of observations. Residue analysis allowed validation of the models (Figs. 6-8), since the majority of the Pearson residuals appears to be randomized and there is a clear linear relationship between the Pearson residuals and the expected normal quantiles.

As expected, addition of variables and variable interactions reduced model deviance and degrees of freedom when compared to the null model, which comprises no explanatory variables (Table 3 ). The main effects model retrieved sediment $\mathrm{Cd}$ concentration as the most relevant variable influencing liver MT values. The following most relevant component was liver $\mathrm{Cd}$ concentration, close to the critical $p$-value of rejection. Nonetheless, neither component produced a significant regression coefficient $(p>0.05)$. The low variability between stations regarding sediment $\mathrm{Cd}$ and, as a consequence, the low significance of its respective coefficient, compromise the importance of this a

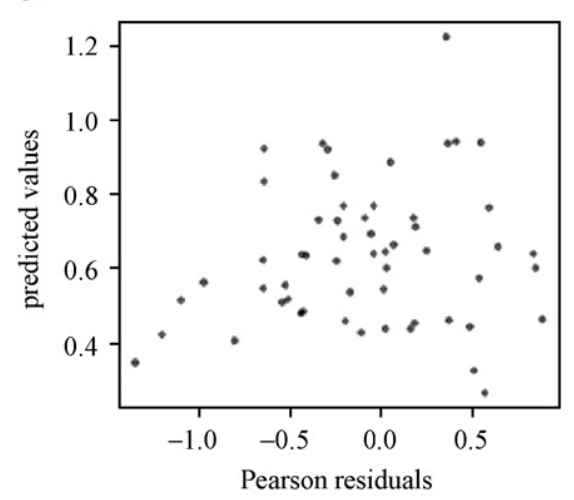

b

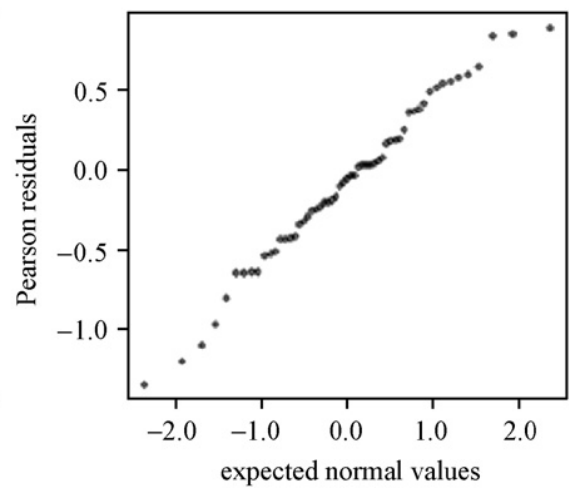

Fig. 6. Main effects model validation. (a) Dispersion of Pearson residuals $\times$ predicted model values. (b) Pearson residuals $\times$ expected normal values.

a

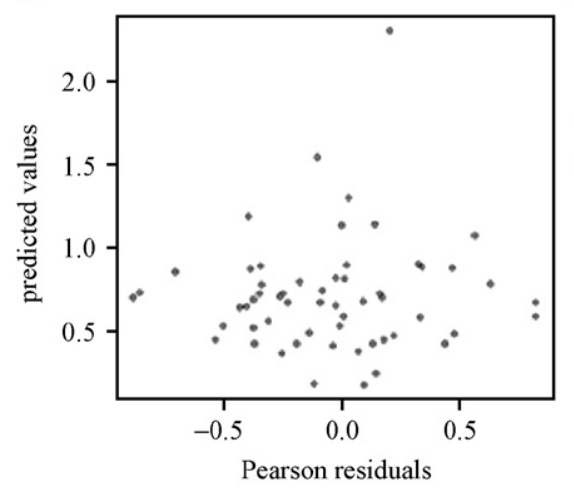

b

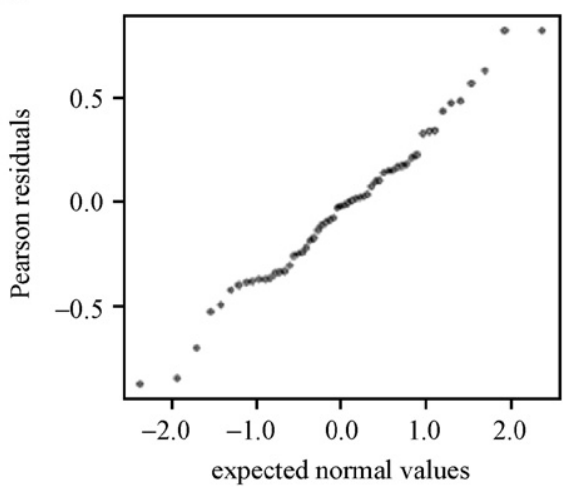

Fig. 7. Validation of the interaction model liver metal content*sediment metal content. (a) Dispersion of Pearson residuals $\times$ predicted model values. (b) Pearson residuals $\times$ expected normal values. 
a

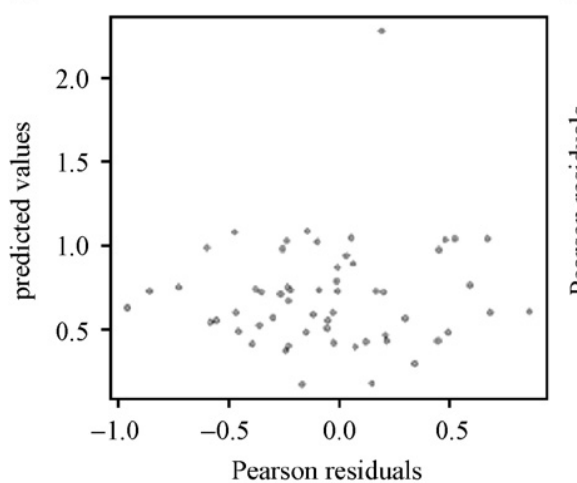

b

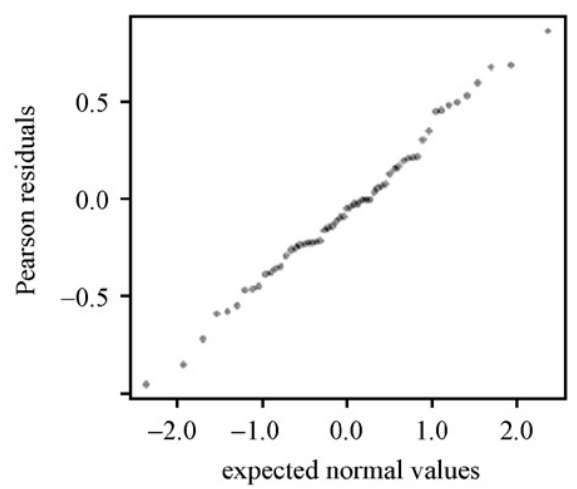

Fig. 8. Validation of the interaction model metal content $*$ sediment total organic matter. (a) Dispersion of Pearson residuals $\times$ predicted model values. (b) Pearson residuals $\times$ expected normal values.

Table 3

Model degrees of freedom (df) and deviances

\begin{tabular}{lcc}
\hline Model & df & Deviance \\
\hline Null & 56 & 20.32 \\
Principal components & 47 & 15.11 \\
Interaction between metallic & 43 & 7.71 \\
contents liver/sediment & & \\
Interaction between metallic & 43 & 8.07 \\
contents and organic matter in & & \\
sediment & & \\
\hline
\end{tabular}

variable in the present study while liver $\mathrm{Cd}$ concentration detains a more significant role in explaining MT levels. The interaction model liver*sediment metallic concentrations retrieved a very significant positive interaction between liver and sediment $\mathrm{Cu}$ influencing MT levels $(p \approx 0.00)$. The second interaction model retrieved a strong positive interaction between liver $\mathrm{Cu}$ and sediment TOM $(p \approx 0.00)$. These results reveal interaction models to be more effective explaining MT induction than isolated variables and that liver Cd may be linked to MT induction although no significant variation in sediment $\mathrm{Cd}$ between sites was found. GLM results are summarized in Table 4.

\section{Discussion and conclusions}

The method used to extract MT failed to remove all nonheat stable HMW proteins, similarly to what has been observed in similar works on marine organisms that used the same extraction method (Bustamante et al., 2002; Correia et al., 2004). Nevertheless, the remaining HMW proteins are not metal-induced and should not interfere with the assessment of MT induction as a biomarker of metal contamination (Bebianno et al., 1992). Polymerization of monomeric MT of $S$. aurata and rabbit occurred (as inferred from the HMW of the bands), probably during electrophoresis, most likely due to the existence of metalfree sulphydryl groups (Suzuki et al., 1998). The observed molecular weight of polymerized MT differs from the most common polymerized forms of vertebrate MT, namely dimeric, trimeric and tetrameric forms, found by other authors using various extraction and electrophoresis methods, although band pattern is similar (Suzuki et al., 1998, Xie and Klerks, 2004; Shen et al., 2006). Polymerization of MTs is not yet completely understood and is probably dependent of extraction and electrophoresis parameters such as $\mathrm{pH}$, since acidic media facilitate metal releasing from sulphydryl groups (Sanz-Nebot et al., 2003). The observed compatibility between $S$. aurata and the standard MT in terms of electrochemical and electrophoretic behavior confirmed the suitability of the method used to quantify $S$. aurata MT.

A strong interaction between liver and sediment $\mathrm{Cu}$ was observed, indicating that organisms bioaccumulated $\mathrm{Cu}$ from the sediment and that this interaction contributed to an increase (induction) of MT synthesis in the liver. Sediment organic matter is known to negatively affect metal bioavailability since metals have high affinity with the organic carbon matrix. For such reason, sediments may act as a "sink" that removes metals from the water column (Caccia et al., 2003; Mota et al., 2005). Nevertheless, the positive interaction between $\mathrm{Cu}$ in liver and sediment organic matter can be explained by factors influencing bioavailability of metals in the sediment, such as $\mathrm{pH}$, redox potential and resuspension, that may have caused metals to release from the organic matrix (Mucha et al., 2004; Geffard et al., 2005; Gillis et al., 2006). Sediment resuspension upon assembling of assays and scavenging activity of the animals may have had a strong impact on the high metal levels found in the liver of exposed individuals, mainly $\mathrm{Cu}$ and $\mathrm{Pb}$. Sites $\mathrm{C} 1$ and $\mathrm{C} 2$, in which there was observed high bioaccumulation (especially $\mathrm{Cu}$ and $\mathrm{Pb}$ ), although sediment metallic levels were low, have small TOM and FF levels that, combined with resuspension, may have increased metal bioavailability. Sediments from sites A, B and C had the highest metal levels but their high TOM contents and FF may have not prevented a strong release of metallic contaminants to the water. Conversely, sediment from site $\mathrm{D}$ also has high TOM content and FF but lower metal levels 
Table 4

Most relevant GLM components and respective coefficients

\begin{tabular}{|c|c|c|c|c|}
\hline Model & Component & Component $p$ ( $F$-test $)$ & Coefficient & Coefficient $p$ ( $t$-test) \\
\hline \multicolumn{5}{|l|}{ Main effects model } \\
\hline & Sediment Cd & $0.03^{*}$ & - & 0.68 \\
\hline & Liver Cd & 0.06 & - & 0.28 \\
\hline \multicolumn{5}{|l|}{ Interaction models } \\
\hline Liver*sediment metals & Liver $\mathrm{Cu} \times$ sediment $\mathrm{Cu}$ & $\approx 0.00^{* *}$ & Positive & $\approx 0.00^{* *}$ \\
\hline Metal*sediment OM & Liver $\mathrm{Cu} \times \mathrm{TOM}$ & $\approx 0.00^{* *}$ & Positive & $\approx 0.00^{* *}$ \\
\hline
\end{tabular}

*Significant value, $p<0.05 ;{ }^{* *}$ significant value, $p<0.01$.

than sites $\mathrm{A}, \mathrm{B}$ and $\mathrm{C}$, which probably relates to the lower bioaccumulation observed.

Although statistical analysis derived liver $\mathrm{Cd}$ as a relevant factor influencing MT induction, it was not possible to infer the nature of such influence. The difficulty to quantify this interference is most likely related to the low levels of $\mathrm{Cd}$ found in the sediment and in the liver. Complementarily, $\mathrm{Cu}$, which is well represented in both, has been found a weak MT inducer (Olsson and Haux, 1986). It has in fact been suggested that exposure to low levels and consequent weak bioaccumulation of strong MT inducers, such as $\mathrm{Cd}$, may compromise the use of $\mathrm{MT}$ quantification as a biomarker (Mouneyrac et al., 2002). GLM analysis, however, still permitted the inference on the most relevant factors related to MT induction, showing that statistical modelling may reliably overcome issues associated to high data variability when multiple variables are involved.

Many biological variables, such as age and sex, can also influence MT induction, thus increasing the variability of the response (Hamza-Chaffai et al., 1995). The role of these variables on MT induction is not yet quite understood and thus may pose as an important constraint towards the employment of MT induction as an effective biomarker of metal contamination. Alarcón et al. (2004), for instance, disclose the existence of high genetic variability within $S$. aurata aquaculture and natural populations when compared to other sparids. This information contributes to the understanding that individual differences may explain some of the high heterogeneity in MT induction.

The interaction between contaminants also plays an important part as a confounding factor for MT induction, including the interaction between metallic and organic toxicants (Roméo et al., 1997), and for this reason the use of mathematical models to explain multiple-metal interactions over toxicity effects has already been proposed (Playle, 2004). The combination of all these factors points towards the need to integrate biomarkers and biological and environmental variables when applying a practical biomonitoring procedure (Cajaraville et al., 2000).

The integration of a biomarker such as MT induction with liver metallic content and sediment parameters through GLM analysis allowed the discrimination of factors influencing liver MT concentration, whereas more classic stand-alone approaches failed to do so. Statistical modelling proved to be a useful tool to integrate the variables under study, but may require an extensive sampling procedure as more variables are added, as well as a good a priori knowledge concerning the explanatory variables and a keen sense to maintain model parsimony. The present work reinforces the need to integrate fundamental environmental parameters when it comes to applying one or more biomarkers in a practical sediment risk assessment procedure and confirms the suitability of GLM for this purpose.

\section{Acknowledgements}

The present research was approved by the Portuguese Science and Technology Foundation and POCTI (Research Project POCTI/AMB 57281/104) and financed by FEDER. The authors would like to thank C. Vale and M. Caetano (IPIMAR, Lisboa), TIMAR/Ria-Mãe (Setúbal), CONTROLAB (Portugal), and A. Duarte, M. Guilherme and A. Pereira (REQUIMTE) for their support.

\section{References}

Alarcón, J.A., Magoulas, A., Georgakopoulos, T., Zouros, E., Alvareza, M.C., 2004. Genetic comparison of wild and cultivated European populations of the gilthead sea bream (Sparus aurata). Aquaculture 230, 65-80.

Bebianno, M.J., Langston, W.J., 1989. Quantification of metallothioneins in marine invertebrates using differential pulse polarography. Port. Electrochim. Acta 7, 59-64.

Bebianno, M.J., Langston, W.J., Simkiss, K., 1992. Metallothionein induction in Littorina littorea (Mollusca: Prosobranchia) on exposure to cadmium. J. Mar. Biol. Assoc. UK 72, 329-342.

Bustamante, P., Cosson, R.P., Gallien, I., Caurant, F., Miramand, P., 2002. Cadmium detoxification processes in the digestive gland of cephalopods in relation to accumulated cadmium concentrations. Mar. Environ. Res. 53, 227-241.

Caccia, V.G., Millero, F.J., Palanques, A., 2003. The distribution of trace metals in Florida Bay sediments. Mar. Pollut. Bull. 46, 1420-1433.

Caeiro, S., Costa, M.H., Ramos, T.B., Fernandes, F., Silveira, N., Coimbra, A., Medeiros, G., Painho, M., 2005. Assessing heavy metal contamination in Sado Estuary sediment: an index analysis approach. Ecol. Indicators 5, 151-169.

Cajaraville, M.P., Bebianno, M.J., Blasco, J., Porte, C., Sarasquete, C., Viarengo, A., 2000. The use of biomarkers to assess the impact of pollution in coastal environments of the Iberian Peninsula: a practical approach. Sci. Total Environ. 247, 295-311. 
Clescer, L.S., Greenberg, A.E., Eaton, A.D. (Eds.), 1999. Standard Methods for Examination of Water \& Wastewater, 20th edn. American Public Health Association, Baltimore.

Correia, A.D., Sousa, A., Costa, M.H., Moura, I., Livingstone, D.R. 2004. Quantification of metallothionein expression in whole body Gammarus locusta (Crustacea: Amphipoda) using differential pulse polarography. Toxicol. Environ. Chem. 86, 23-36.

Cousinou, M., Dorado, G., López-Barea, J., 1999. Amplification and cloning of cDNAS of cytochrome P4501A1 and metallothionein genes from Sparus aurata Linnaeus, 1758 and Liza aurata (Risso, 1810) by Race-PCR. Bol. Inst. Esp. Oceanogr. 15, 473-484.

DelValls, T.A., Blasco, J., Sarasquete, M.C., Forja, J.M., Gomez-Parra, A., 1998. Evaluation of heavy metal sediment toxicity in littoral ecosystems using juveniles of the fish Sparus aurata. Ecotoxicol. Environ. Saf. 41, 157-167.

DelValls, T.A., Forja, J.M., Gómez-Parra, A., 2002. Seasonality of contamination, toxicity, and quality values in sediments from littoral ecosystems in the Gulf of Cádiz (SW Spain). Chemosphere 46, 1033-1043.

Fulladosa, E., Deane, E., Ng, A.H.Y., Woo, N.Y.S., Murat, J.C., Villaescusa, I., 2006. Stress proteins induced by exposure to sublethal levels of heavy metals in sea bream (Sparus sarba) blood cells. Toxicol. In Vitro 20, 96-100.

Geffard, O., Geffard, A., Budzinski, H., Crouzet, C., Menasria, R., Amiard, J., Amiard-Triquet, C., 2005. Mobility and potential toxicity of sediment-bound metals in a tidal estuary. Environ. Toxicol. 20, 407-417.

Gillis, P.L., Wood, C.M., Ranville, J.F., Chow-Fraser, P., 2006. Bioavailability of sediment-associated $\mathrm{Cu}$ and $\mathrm{Zn}$ to Daphnia magna. Aquat. Toxicol. 77, 402-411.

Hamza-Chaffai, A., Cosson, R.P., Amiard-Triquet, C., El-Abed, A., 1995. Physico-chemical forms of storage of metals $(\mathrm{Cd}, \mathrm{Cu}$ and $\mathrm{Zn})$ and metallothionein-like proteins in gills and liver of marine fish from the Tunisian coast: ecotoxicological consequences. Comp. Biochem. Physiol. C 111, 329-341.

Ihaka, R., Gentleman, R., 1996. R: a language for data analysis and graphics. J. Comput. Graph. Stat. 5, 299-314.

Margoshes, M., Vallee, B.L., 1957. A cadmium protein from equine kidney cortex. J. Am. Chem. Soc. 79, 4813-4819.

McCullagh, P., Nelder, J.A., 1989. Generalized Linear Models, 2nd edn. Chapman \& Hall, London.

Mota, A.M., Cruz, P., Vilhena, C., Gonçalves, M.L.S., 2005. Influence of the sediment on lead speciation in the Tagus estuary. Water Res. 39, 1451-1460.

Mouneyrac, C., Amiard, J.C., Amiard-Triquet, C., Cottier, A., Rainbow, P.S., Smith, B.D., 2002. Partitioning of accumulated trace metals in the talitrid amphipod crustacean Orchestia gammarellus: a cautionary tale on the use of metallothionein-like proteins as biomarkers. Aquat. Toxicol. 57, 225-242.

Mucha, A.P., Vasconcelos, M.T.S.D., Bordalo, A.A., 2004. Vertical distribution of the macrobenthic community and its relationships to trace metals and natural sediment characteristics in the lower Douro estuary, Portugal. Estuar. Coast. Shelf Sci. 59, 663-673.

Nelder, J.A., Wedderburn, R.W., 1972. Generalized linear models. J. Roy. Stat. Soc. A 135, 370-384.

Neuparth, T., Correia, A.D., Costa, F.O., Lima, G., Costa, M.H., 2005. Multi-level assessment of chronic toxicity of estuarine sediments with the amphipod Gammarus locusta: I. Biochemical endpoints. Mar. Environ. Res. 60, 69-91.

Olsson, P.-E., Haux, C., 1986. Increased hepatic metallothionein content correlates to cadmium accumulation in environmentally exposed perch (Perca fluviatilis). Aquat. Toxicol. 9, 231-242.

Palecek, E., Pechan, Z., 1971. Estimation of nanogram quantities of proteins by pulse polographic techniques. Anal. Biochem. 42, 59-71.

Playle, R.C., 2004. Using multiple metal-gill binding models and the toxic unit concept to help reconcile multiple-metal toxicity results. Aquat. Toxicol. 67, 359-370.

Roméo, M., Cosson, R.P., Gnassia-Barelli, M., Risso, C., Stien, X., Lafaurie, M., 1997. Metallothionein determination in the liver of the sea bass Dicentrarchus labrax treated with copper and B(a)P. Mar. Environ. Res. 44, 275-284.

Romero-Isart, N., Vašák, M., 2002. Advances in the structure and chemistry of metallothioneins. J. Inorg. Biochem. 88, 388-396.

Sanz-Nebot, V., Andón, B., Barbosa, J., 2003. Characterization of metallothionein isoforms from rabbit liver by liquid chromatography coupled to electrospray mass spectrometry. J. Chromatogr. B 796, 379-393.

Shen, J.-C., Liu, J., Zhuang, Z.-X., Wang, X.-R., Lee, F.S.C., 2006. Investigation of zinc binding metallothioneins' polymerization in tris(hydroxymethyl)-aminomethane buffer by coupling of size exclusion chromatography with electrospray ionization mass spectrometry. Talanta 69, 988-995.

Suzuki, J.S., Kodama, N., Molotov, A., Aoki, E., Tohyama, C., 1998. Isolation and identification of metallothionein isoforms (MT-1 and MT-2) in the rat testis. Biochem. J. 334, 695-701.

Tom, M., Moran, O., Jabukov, E., Cavari, B., Rinkevitch, B., 1998. Molecular characterization of metallothionein-cDNA of Sparus aurata used for detecting heavy metal pollution along the Mediterranean coast of Israel. Mar. Pollut. Bull. 36, 131-137.

Tom, M., Chen, N., Segev, M., Herut, B., Rinkevitch, B., 2004 Quantifying fish metallothionein transcript by real time PCR for its utilization as an environmental biomarker. Mar. Pollut. Bull. 48, 705-710.

USEPA, 1996. Method 3050B-Acid Digestion of Sediments, Sludges, and Soils. US Environmental Protection Agency, Washington DC.

Wan, M., Hunziker, P.E., Kägi, J.H.R., 1993. Induction of metallothionein synthesis by cadmium and zinc in cultured rabbit kidney cells (RK-13). Biochem. J. 292, 609-615.

Xie, L., Klerks, P.L., 2004. Metallothionein-like protein in the least killifish Heterandria formosa and its role in cadmium resistance. Environ. Toxicol. Chem. 23, 173-177. 